\title{
Reduced thymocyte proliferation but not increased apoptosis as a possible cause of thymus atrophy in iron-deficient mice
}

\author{
Solo R. Kuvibidila ${ }^{1}$, Connie Porretta ${ }^{2}$, B. Surendra Baliga ${ }^{3}$ and Lily E. Leiva ${ }^{1}$ \\ ${ }^{1}$ Department of Pediatrics, Divisions of Hematology/Oncology and Allergy/Immunology, Louisiana State University Health \\ Sciences Center, 1542 Tulane Avenue, New Orleans LA 70112, USA \\ ${ }^{2}$ Department of Pulmonary Medicine, Louisiana State University, Health Sciences Center, 1542 Tulane Avenue, New Orleans \\ LA 70112, USA \\ ${ }^{3}$ Department of Pediatrics, University of South Alabama College of Medicine, 2451 Fillingim Street, Mobile AL 36617, USA
}

(Received 4 October 2000 - Revised 10 January 2001 - Accepted 30 January 2001)

\begin{abstract}
Iron deficiency induces thymus atrophy in laboratory animals and very likely in humans by unknown mechanisms. The atrophy is associated with impaired cell-mediated immunity. In this study, we tested the hypothesis that thymus atrophy is a result of increased apoptosis and reduced thymocyte proliferation. Thymocytes were obtained from twenty-seven control, twentyseven pairfed, twenty-seven iron-deficient (ID) mice; twelve and fourteen ID mice that received the control diet $\left(0.9 \mathrm{mmol} / \mathrm{kg}\right.$ versus $0.09 \mathrm{mmol} / \mathrm{kg}$ for the ID diet) for $1 \mathrm{~d}$ (repletion, $\left.\mathrm{R}_{1}\right)$ and $3 \mathrm{~d}\left(\mathrm{R}_{3}\right)$, respectively. Cell cycle analysis and apoptosis were studied by flow cytometry using propidium iodide staining and terminal deoxyuridine nick end labeling of DNA breaks assay respectively. When mice were killed, haemoglobin, haematocrit, and liver iron stores of ID, $\mathrm{R}_{1}$, and $\mathrm{R}_{3}$ mice were $25-40 \%$ of those of control and pairfed mice $(P<0.01)$. Absolute and relative thymus weights and thymocyte numbers were 19 to $68 \%$ lower in ID, $\mathrm{R}_{1}$, and $\mathrm{R}_{3}$ than in control and pairfed groups $(P<0 \cdot 05)$. We found no significant difference among groups in the percentage of cells undergoing apoptosis. A higher percentage of thymocytes from ID and $\mathrm{R}_{1}$ mice than those of control, pairfed, and $\mathrm{R}_{3}$ mice were in the resting phase of the normal cell cycle $(P<0.05)$. Conversely, a lower percentage of thymocytes from ID and $\mathrm{R}_{1}$ mice than those from control, pairfed, and $\mathrm{R}_{3}$ mice were in the DNA synthesis phase and late phase of DNA synthesis and onset of mitosis $\left(\mathrm{G}_{2}-\mathrm{M}\right)(P<0.05)$. Indicators of iron status positively correlated $(r 0.3$ to 0.56$)$ with the percentage of thymocytes in the $\mathrm{G}_{2}-\mathrm{M}$ phase $(P<0.05)$. Results suggest that reduced cell proliferation but not increased apoptosis is the cause of thymus atrophy associated with iron deficiency.
\end{abstract}

Iron deficiency: Haemoglobin: Thymus atrophy: Cell cycle analysis

Haematopoietic stem cell precursors of mature $\mathrm{T}$ cells originate from the bone marrow and migrate to the thymus, which is the major site of T lymphocyte maturation. Within the cortex of the thymus, precursors of $\mathrm{T}$ cells undergo extensive cell proliferation, but more than $95 \%$ of thymocytes die by apoptosis before they reach the medulla and the blood stream (Abbas et al. 1997). This natural apoptotic process allows negative and positive selection and promotes the differentiation of thymocytes to mature $\mathrm{CD}^{+} / \mathrm{CD}^{-}$and $\mathrm{CD} 4^{-} / \mathrm{CD}^{+}{ }^{+} \mathrm{T}$ lymphocytes.

Thymus involution or atrophy is a natural phenomenon that occurs during ageing of humans and animals.
However, during protein-energy malnutrition and certain single nutrient deficiencies, thymus atrophy occurs in young children and laboratory animals (Smythe et al. 1971; Chandra \& Newberne, 1977; Nauss et al. 1979). This atrophy is very likely responsible for decreased circulating number of white blood cells and total lymphocytes as well as T-cell numbers in children and laboratory animals with protein-energy malnutrition, zinc deficiency, vitamin A deficiency, and iron deficiency (Kuvibidila et al. 1993). It probably also contributes to reduced cell-mediated immunity associated with ageing. The mechanism of thymus atrophy is unknown. In children suffering from protein-

\footnotetext{
Abbreviations: $\mathrm{C}$, control; $\mathrm{G}_{0}-\mathrm{G}_{1}$, resting phase of the normal cell cycle; $\mathrm{G}_{2}-\mathrm{M}$, late phase of DNA synthesis and onset of mitosis; ID, iron deficient; PF, pairfed; R, iron repleted; S, (DNA) synthesis phase.

* Corresponding author: Dr S. R. Kuvibidila, fax +1 504568 3078, email skuvib@1suhsc.edu
} 
energy malnutrition and in zinc-deficient laboratory mice, thymus atrophy is thought to be due to apoptosis induced by high levels of cortisol (Alleyne \& Young, 1967; DePascal-Jardieu \& Fraker, 1979; Smith et al. 1981; Becker, 1983). However, thymus atrophy may also be due to several other causes such as reduced cell proliferation in the thymus, reduced proliferation and migration of precursor cells (haematopoietic stem cells) from the bone marrow to the thymus, and increased cell migration from the thymus to peripheral lymphoid organs such as the lymph nodes and spleen.

Previous studies of the effects of iron deficiency on cellmediated immunity in laboratory animals conducted by our group (Kuvibidila et al. 1990, 1998, 1999) and Kochanowiski \& Sherman (1982) showed that thymus atrophy is also very common in laboratory mice and rats. In one of our studies, histology of the thymus indicated depletion of thymocytes in the medulla and the cortex of iron-deficient mice compared to those from control and pairfed mice (Kuvibidila et al. 1990). The mechanism of thymocyte depletion has not been previously investigated. We hypothesized that thymus atrophy in iron deficiency occurs as a result of increased apoptosis and reduced in vivo thymocyte proliferation.

\section{Methods \\ Source of reagents}

Various reagents used in the study were purchased from the following companies: penicillin, streptomycin, PBS from Gibco (Grand Island, NY, USA); DNase RNase-free, iron assay kits, Drabkin's reagents, haemoglobin standard from Sigma (St Louis, MO, USA); propidium iodide, RNase DNase-free, in situ cell death detection kit (reagents for assay of terminal deoxyuridine nick end labelling) from Boeringer Mannheim Co (Indianapolis, IN, USA); irondeficient and control diets from Harlan Teklan (Indianapolis, IN, USA); ethanol from AAPER Alcohol and Chemical Co (Shelbyville, KT, USA).

\section{Induction of iron deficiency}

Three-week old female C57BL/6 mice were obtained from Charles River breeding laboratories (Wilmington, MA, USA). During the first $7 \mathrm{~d}$, all mice were given the ironsupplemented diet that contained $50 \mathrm{mg}$ iron $/ \mathrm{kg}$ diet $(0.895 \mathrm{mmol} / \mathrm{kg})$. At the end of the adjustment period, they were randomly assigned to either the control (C, $n$ 27), the iron deficient (ID, $n$ 53), or the pairfed (PF, $n$ 27) groups. Both the experimental and the iron-supplemented diet had identical composition in regard to proteins, fat, carbohydrates, minerals, vitamins, and trace elements except for the iron concentrations (Kuvibidila et al. 1998). The test diet contained $0.0895 \mathrm{mmol}$ iron $/ \mathrm{kg}$ $(5 \mathrm{mg} / \mathrm{kg})$ and the control diet $0.895 \mathrm{mmol} / \mathrm{kg}$. While C and the ID mice had free access to their food $24 \mathrm{~h} / \mathrm{d}, \mathrm{PF}$ mice received the mean amount of food that ID mice had consumed during the preceding $24 \mathrm{~h}$. The PF group was added to account for the effects of reduced food intake associated with severe iron deficiency anaemia. Mice received sterile deionized water and were housed in sterile microisolators. The light-dark cycle of the vivarium room was set for $12 \mathrm{~h}$, and the temperature at $22^{\circ} \mathrm{C}$. Twelve and fourteen ID mice received the iron-supplemented diet for $1 \mathrm{~d}$ (repletion protocol, $\left.\mathrm{R}_{1}\right)$ and $3 \mathrm{~d}\left(\mathrm{R}_{3}\right)$ respectively prior to killing. Mice were killed when the haemoglobin concentrations of those receiving the test diet decreased below $70 \mathrm{~g} / \mathrm{l}$ (normal values equal or greater than $120 \mathrm{~g} / \mathrm{l}$ ). The protocol was approved by the Institutional Animal Care and Use Committee of Louisiana State University Health Sciences Center.

\section{Estimation of the relative thymus weight}

When mice were killed, they were 3 months old (68 d from the time they were assigned to either the experimental, the control, or the pairfed group). At the time of death, they were anaesthetized by ether inhalation for 30-60 s. Each mouse was immediately weighed on a Model CT200 Ohaus balance. After as much blood as possible was drawn from the retro-orbital plexus, mice were killed by cervical dislocation. In each experiment at least one mouse was used from each experimental group. The thymus was removed under sterile conditions, placed in a preweighed culture tube that contained $1 \mathrm{ml}$ of wash medium (RPMI1640, supplemented with $25 \mathrm{mmol} / \mathrm{l}$ HEPES, $5 \mathrm{~g} / \mathrm{l}$ bovine serum albumin, $50 \mathrm{mg} / 1$ streptomycin, and $50000 \mathrm{IU} / 1$ penicillin). Relative thymus weight was determined by dividing thymus weight in $\mathrm{mg}$ by body weight in $\mathrm{g}$.

\section{Estimation of iron status at the end of the feeding period}

Packed cell volume was assayed by centrifugation and haemoglobin by the cyanmethaemoglobin methods (Rodak, 1992). Liver iron stores were measured by colorimetry using a kit purchased from Sigma. Detailed information on liver iron assay has been reported (Kuvibidila et al. 1998).

\section{Measurement of thymocytes undergoing apoptosis}

Thymocyte suspensions from individual mice were prepared by standard techniques (Kuvibidila et al. 1998). Red blood cells were lysed by osmotic shock by the use of icecold deionized water during a $30 \mathrm{~s}$ incubation period. After centrifugation of tubes at $400 \mathrm{~g}, 4^{\circ} \mathrm{C}$, for $10 \mathrm{~min}$, the supernatant was decanted. Each pellet was then resuspended in either $2 \mathrm{ml}$ wash medium for $\mathrm{C}$ and $\mathrm{PF}$, or $1 \mathrm{ml}$ for ID and iron-repleted mice. Total and viable cell counts were performed under a light microscope after diluting the cells 1:10. To obtain the total cell number per thymus, the number of cells per $1 \mathrm{ml}$ was multiplied by the volume.

Two million viable cells resuspended in PBS that contained $5 \mathrm{~g} / \mathrm{l}$ bovine serum albumin, $50000 \mathrm{IU} / 1$ penicillin, and $50 \mathrm{mg} / \mathrm{l}$ streptomycin, were transferred to a $12 \times$ $75 \mathrm{~mm}$ sterile plastic culture tube. Tubes were centrifuged at $400 \mathrm{~g}, 4^{\circ} \mathrm{C}$ for $10 \mathrm{~min}$. The supernatant was decanted and each cell pellet was resuspended in $200 \mu \mathrm{l}$ of a freshly prepared solution of $4 \%$ paraformaldehyde. Cells were incubated at room temperature $\left(22^{\circ} \mathrm{C}\right)$ for $30 \mathrm{~min}$ on a shaker (Maxi-Max III, Thermolyne) set at 200 r.p.m. After cells were washed twice at $400 \mathrm{~g}, 4^{\circ} \mathrm{C}$ for $10 \mathrm{~min}, 200 \mu \mathrm{l}$ 
Table 1. Iron status of control, iron-deficient, pairfed mice, and mice that received the iron-supplemented diet for either $1 d\left(R_{1}\right)$ or $3 d\left(R_{3}\right)$ (Values are means and their standard errors for twenty-seven C, PF, ID mice, twelve $R_{1}$ and fourteen $R_{3}$ mice)

\begin{tabular}{lccccccccccc}
\hline & \multicolumn{3}{c}{$\mathrm{C}$} & \multicolumn{3}{c}{$\mathrm{PF}$} & \multicolumn{3}{c}{$\mathrm{ID}$} & $\mathrm{R}_{1}$ & $\mathrm{R}_{3}$ \\
\hline Haemoglobin g/l & 169.7 & $1.87^{\mathrm{a}}$ & 171.5 & $2.42^{\mathrm{a}}$ & 37.89 & $2.31^{\mathrm{c}}$ & 46.5 & $4.90^{\mathrm{c}}$ & $60 \cdot 6$ & $4.74^{\mathrm{b}}$ \\
Packed cell volume (\%) & 49.5 & $0.36^{\mathrm{a}}$ & 51 & $0.42^{\mathrm{a}}$ & 17.4 & $0.93^{\mathrm{c}}$ & 21.1 & $1.62^{\mathrm{c}}$ & 28.96 & $1.73^{\mathrm{b}}$ \\
Liver iron, $\mu \mathrm{mol}$ iron/g & 1.047 & $0.034^{\mathrm{a}}$ & 1.171 & $0.057^{\mathrm{a}}$ & 0.22 & $0.01^{\mathrm{c}}$ & 0.292 & $0.03^{\mathrm{c}}$ & 0.478 & $0.06^{\mathrm{b}}$ \\
\hline
\end{tabular}

$\mathrm{C}$, control; PF, pairfed; ID, iron-deficient; $\mathrm{R}$, iron replete for 1 or $3 \mathrm{~d}$.

Values followed by different letters are significantly different $(P<0.01)$; $a>b>c>d$.

of $0.1 \%$ Triton-X100 in $0.1 \%$ sodium citrate were added to each tube. Cell permeabilization was done for $2 \mathrm{~min}$ on ice, followed by two washes at $400 \mathrm{~g}, 4^{\circ} \mathrm{C}$ for $10 \mathrm{~min}$. To quantify cells undergoing apoptosis, $50 \mu \mathrm{l}$ of the terminal deoxyuridine nick-end labelling mixture were added to each tube. The mixture contained the enzyme terminal deoxynucleotidyl transferase from calf thymus and deoxyuridine triphosphate conjugated with fluorescein isothiocyanate. The test is based on the polymerization of deoxyuridine triphosphate-fluorescein isothiocyanate at the $3^{\prime}-\mathrm{OH}$ termini of DNA strand breaks. For negative controls, the enzyme was omitted. For positive controls, permeabilized thymocytes were incubated with $16 \mu \mathrm{g} / \mathrm{ml}$ DNase at room temperature for $10 \mathrm{~min}$. At the end of the 10 min incubation period, cells were washed twice as described above. Test samples, negative controls, and positive controls were incubated for $60 \mathrm{~min}$ at $37^{\circ} \mathrm{C}$ in a humidified $\mathrm{CO}_{2}$ incubator protected from light for $60 \mathrm{~min}$. Labelled cells were washed twice at $400 \mathrm{~g}, 4^{\circ} \mathrm{C}$ for $10 \mathrm{~min}$. They were examined under the fluorescence microscope (Nikon, Tokyo, Japan) and analysed by flow cytometry (Becton Dickinson, San Jose, CA, USA).

\section{Cell cycle analysis}

The method described by Coligan et al. (1991) was used. Three million viable thymocytes were fixed (within $2 \mathrm{~h}$ of preparation of cell suspension) with ice-cold $70 \%$ ethanol overnight. After cells were washed at $400 \mathrm{~g}$ for $10 \mathrm{~min}$ at $4^{\circ} \mathrm{C}, 1 \mathrm{ml}$ of a solution of propidium iodide $(50 \mathrm{mg} / \mathrm{l})$ was added to each tube. Two micrograms of RNase DNase-free were added to degrade double-stranded RNA. Tubes were vortexed at low speed for $10 \mathrm{~s}$, incubated at room temperature for $60 \mathrm{~min}$, and then at $4^{\circ} \mathrm{C}$ overnight. Between 10000 and 25000 cells were acquired by flow cytometry (FacsCalibur, Becton Dickinson). Cell cycle analysis (resting phase of the normal cell cycle, $\mathrm{G}_{0}-\mathrm{G}_{1} ; \mathrm{S}$, DNA synthesis phase; late phase of DNA synthesis and onset of mitosis, $\mathrm{G}_{2}$-M) was performed using ModFitLT2.0 Software (Verity Software House, Topsham, ME, USA) within $24 \mathrm{~h}$ after staining. Aggregates were discriminated by gating width $v$. area.

\section{Statistical analysis}

Descriptive analysis, ANOVA, and Pearson correlation coefficients were calculated using Microstatistical Program (Microsoft Inc, Indianapolis, IN, USA; Munro et al. 1986). When ANOVA detected significant differences among groups, Scheffe's test was used as a post hoc test to determine which pairs of means were different. The level of significance was set at $P=0 \cdot 05$.

\section{Results}

\section{Food intake and iron status}

There was a small, though significant, decrease in mean (SE) food intake by ID (1.95 (SE 0.14)g) and PF mice (1.98 (SE 0.013)g) compared to $\mathrm{C}$ mice $(2.38$ (SE 0.1)g; $P<$ $0 \cdot 001)$. At the end of the feeding period, ID mice had significantly lower mean indicators of iron status $(P<0 \cdot 01$; Table 1$)$. Feeding ID mice the iron-supplemented diet for 1 and $3 \mathrm{~d}$ improved, but did not correct mean indicators of iron status. However, the mean haemoglobin and packed cell volume of $\mathrm{R}_{3}$ were significantly higher than those of ID mice $(P<0.05)$.

\section{Mean weights of body and thymus, and thymocyte numbers in different groups of mice}

There were significant differences in mean body weight, absolute and relative thymus weights, absolute and relative thymocyte numbers among groups $(P<0.001$; Table 2$)$. All these measurements were significantly lower in ID than in $\mathrm{C}$ and $\mathrm{PF}$ mice $(P<0.05)$. Iron deficiency reduced the

Table 2. The weights of body and thymus, absolute, and relative thymocyte numbers of control, iron-deficient, pairfed, $R_{1}$, and $R_{3}$ mice (Values are means and their standard errors for twenty-seven $C, P F$, ID mice, twelve $R_{1}$ and fourteen $R_{3}$ mice)

\begin{tabular}{|c|c|c|c|c|c|c|c|c|c|c|}
\hline \multirow[b]{2}{*}{ Body weight (g) } & \multicolumn{2}{|c|}{ C } & \multicolumn{2}{|c|}{ PF } & \multicolumn{2}{|c|}{ ID } & \multicolumn{2}{|c|}{$\mathrm{R}_{1}$} & \multicolumn{2}{|c|}{$\mathrm{R}_{3}$} \\
\hline & $21 \cdot 8$ & $0.37^{a}$ & $19 \cdot 4$ & $0.46^{\mathrm{b}}$ & $17 \cdot 7$ & $0.43^{c}$ & $17 \cdot 3$ & $0.83^{c}$ & $18 \cdot 7$ & $0.41^{\mathrm{b}}$ \\
\hline Thymus (mg) & 86.4 & $4.98^{\mathrm{a}}$ & 70 & $3.46^{\mathrm{b}}$ & $46 \cdot 8$ & $4 \cdot 05^{c}$ & $54 \cdot 2$ & $6 \cdot 60^{\mathrm{C}}$ & $36 \cdot 7$ & $3 \cdot 86^{d}$ \\
\hline Thymus (mg/g body weight) & 4.02 & $0.26^{\mathrm{a}}$ & $3 \cdot 6$ & $0 \cdot 15^{\mathrm{a}}$ & $2 \cdot 6$ & $0.20^{\mathrm{b}}$ & 2.99 & $0.32^{b}$ & 1.95 & $0.20^{\mathrm{c}}$ \\
\hline Thymocytes $\times 10^{6}$ /thymus & $89 \cdot 4$ & $8 \cdot 25^{\mathrm{a}}$ & $76 \cdot 2$ & $7 \cdot 21^{\mathrm{a}}$ & $28 \cdot 2$ & $2 \cdot 8^{\mathrm{C}}$ & $41 \cdot 3$ & $4 \cdot 7^{\mathrm{b}}$ & $30 \cdot 1$ & $5 \cdot 44^{\mathrm{b}, \mathrm{c}}$ \\
\hline Thymocytes $\times 10^{6} / \mathrm{mg}$ thymus & $1 \cdot 11$ & $0.13^{a, b}$ & $1 \cdot 16$ & $0 \cdot 12^{\mathrm{a}}$ & $0 . \overline{6}$ & $0.05^{\mathrm{c}}$ & 0.8 & $0.46^{\mathrm{b}}$ & 0.89 & $0.12^{\mathrm{b}}$ \\
\hline
\end{tabular}


Table 3. Distribution of thymocytes in different phases of the cell cycle in control, pairfed, iron-deficient, $R_{1}$ or $R_{3}$ mice (Values are means and their standard errors for twenty-seven C, PF, ID mice, twelve $R$, and fourteen $R_{3}$ mice)

\begin{tabular}{lcccccccccc}
\hline & \multicolumn{3}{c}{$\mathrm{C}$} & \multicolumn{2}{c}{$\mathrm{PF}$} & \multicolumn{3}{c}{$\mathrm{ID}$} & $\mathrm{R}_{1}$ & $\mathrm{R}_{3}$ \\
\hline $\mathrm{G}_{0}-\mathrm{G}_{1}(\%)$ & 87.3 & $0.87^{\mathrm{b}}$ & 86.8 & $1.0^{\mathrm{b}}$ & 90 & $0.91^{\mathrm{a}}$ & 90 & $0.76^{\mathrm{a}}$ & 84.4 & $1.84^{\mathrm{c}}$ \\
$\mathrm{S}(\%)$ & 9.94 & $0.68^{\mathrm{bc}}$ & 10.4 & $0.81^{\mathrm{b}}$ & 8.4 & $0.79^{\mathrm{c}}$ & 8.1 & $0.64^{\mathrm{b}}$ & 12.6 & $1.47^{\mathrm{a}}$ \\
$\mathrm{G}_{2}-\mathrm{M}(\%)$ & 2.77 & $0.23^{\mathrm{a}}$ & 2.78 & $0.23^{\mathrm{a}}$ & 1.9 & $0.16^{\mathrm{b}}$ & 1.8 & $0.18^{\mathrm{b}}$ & 2.93 & $0.45^{\mathrm{a}}$ \\
$\left(\mathrm{S}+\left[\mathrm{G}_{2}-\mathrm{M}\right]\right)(\%)$ & 12.7 & $0.86^{\mathrm{a}}$ & 13.2 & $1.0^{\mathrm{a}}$ & 9.8 & $0.95^{\mathrm{b}}$ & 9.9 & $0.77^{\mathrm{b}}$ & 15.4 & $1.88^{\mathrm{a}}$ \\
{$\left[\mathrm{S}+\left(\mathrm{G}_{2} / \mathrm{M}\right)\right) / \mathrm{G}_{\mathrm{o}}-\mathrm{G}_{1}$} & 0.15 & $0.01^{\mathrm{a}}$ & 0.16 & $0.01^{\mathrm{a}}$ & 0.1 & $0.01^{\mathrm{b}}$ & 0.1 & $0.01^{\mathrm{b}}$ & 0.19 & $0.03^{\mathrm{a}}$ \\
\hline
\end{tabular}

$\mathrm{C}$, control; PF, pairfed; ID, iron deficient; $R$, iron replete after 1 or $3 \mathrm{~d} ; \mathrm{G}_{0}-\mathrm{G}_{1}$, resting phase of the normal cell cycle; $\mathrm{S}$, DNA synthesis phase; $\mathrm{G}_{2}-\mathrm{M}_{\text {, late }}$ phase of DNA synthesis and onset of mitosis.

Values followed by different letters are significantly different $(P<0.05)$; $\mathrm{a}>\mathrm{b}>\mathrm{c}$.

absolute and relative thymus weights by 46 and $35 \cdot 3 \%$ respectively; and the absolute and relative thymocyte numbers by 68.4 and $46 \%$ respectively compared to $\mathrm{C}$ mice $(P<0.05)$. Underfeeding in PF mice also resulted in a small decrease in the mean body weight $(11.7 \%)$, absolute thymus weight $(17.8 \%)$, relative thymus weight $(10.4 \%)$, and absolute thymocyte numbers (14.7\%). However, the differences between the $\mathrm{PF}$ and $\mathrm{C}$ mice were significant only for body weight $(P<0 \cdot 05)$. Underfeeding in PF mice did not affect the relative thymocyte numbers. Feeding ID mice the control diet for $1 \mathrm{~d}$ improved, but did not correct body weight, absolute or relative thymus weight or thymocyte numbers. Feeding ID mice the control diet for $3 \mathrm{~d}$ did not improve thymus weight, probably in part due to the severity and duration of iron deficiency prior to iron repletion. During the 7 to $10 \mathrm{~d}$ prior to iron repletion, ten of the fourteen mice that were assigned to the $\mathrm{R}_{3}$ group had a packed cell volume equal or less than $20 \%$, compared with only six of the twelve mice assigned to the $\mathrm{R}_{1}$ group. Although the relative thymocyte numbers were slightly lower in $R_{1}$ and $R_{3}$ than in $C$ and $P F$ groups, the differences were not statistically significant $(P>0.05)$. Thymus atrophy was defined as the relative thymus weight below $2.48 \mathrm{mg} / \mathrm{g}$ body weight, which was the lowest observed in $\mathrm{C}$ mice. Thymus atrophy was present in $41 \%$ of ID mice, and $45 \%$ in all mice that received the test diet. Only one PF mouse $(3.7 \%)$ had thymus atrophy.

\section{Analysis of cells undergoing apoptosis}

When thymocytes that were treated with DNase (positive control) were examined under the microscope, $100 \%$ had green fluorescence, which implied that they had DNA breaks. We observed no great differences among groups for mean fluorescence intensity or percentage of thymocytes undergoing apoptosis in vivo (data not shown). In all groups, less than $5 \%$ of thymocytes were undergoing apoptosis and more than $95 \%$ were viable. These results are in agreement with those obtained by trypan blue exclusion test that showed between 96.8 and $98.8 \%$ viable thymocytes in the five groups.

\section{Cell cycle analysis}

We observed significant differences among the five groups in the percentages of thymocytes in different phases of the cell cycle (Table $3 P<0 \cdot 01$ ). In the ID and $\mathrm{R}_{1}$ groups, $90 \%$ of thymocytes were in the resting phase $\left(\mathrm{G}_{0}-\mathrm{G}_{1}\right)$, compared to $87 \%$ in $\mathrm{C}$ and $\mathrm{PF}$ mice $(P<0.05)$. A lower percentage of thymocytes from ID and $\mathrm{R}_{1}$ mice than those from $\mathrm{C}$ and $\mathrm{PF}$ mice were in the $\mathrm{S}$ and $\mathrm{G}_{2}-\mathrm{M}$ phases $(P<$ $0 \cdot 05)$. The sum of thymocytes in the $\mathrm{S}$ and $\mathrm{G}_{2}-\mathrm{M}$ phases as well as the proliferative indexes $\left\{\left[\mathrm{S}+\left(\mathrm{G}_{2}-\mathrm{M}\right)\right] /\left(\mathrm{G}_{0}-\mathrm{G}_{2}\right)\right\}$ were also significantly lower in the ID and $\mathrm{R}_{1}$ group than in the $\mathrm{C}$ and $\mathrm{PF}$ groups $(P<0 \cdot 05)$. Refeeding ID mice the iron-supplemented diet for $3 \mathrm{~d}\left(\mathrm{R}_{3}\right)$ significantly reduced the percentage of thymocytes in the resting phase, and increased the percentages of the cells in the $S$ and $G_{2}-M$ phases, as well as the proliferative index. In fact, the percentage of thymocytes in the $\mathrm{G}_{0}-\mathrm{G}_{1}$ of the $\mathrm{R}_{3}$ group became significantly lower $(P<0.05)$ and those in the $\mathrm{S}$ and $\mathrm{G}_{2}-\mathrm{M}$ phases slightly higher than those of $\mathrm{C}$ and $\mathrm{PF}$ mice $(P>0 \cdot 05)$. In addition, the percentages of thymocytes in the $S$ and $G_{2}-M$ phases, the sum of $S$ and $G_{2}-M$, and the proliferative indexes were significantly higher in the $\mathrm{R}_{3}$ than ID and $\mathrm{R}_{1}$ group $(P<0.05)$.

Results on iron status, absolute and relative thymocyte numbers, and cell cycle analysis were further analysed as a function of thymus atrophy. In the ID group, eleven mice had thymus atrophy and sixteen had thymus weight in the low normal range. ID mice with thymus atrophy tended to have lower mean levels of haemoglobin, packed cell volume, absolute and relative thymocyte numbers than those without thymus atrophy (Table 4). However, ID mice without thymus atrophy still had lower means of indicators of iron status and thymus weights than $\mathrm{C}$ or $\mathrm{PF}$ mice (compare to Tables 1 and 2). In contrast to the trend in body iron status, we found no significant difference in the distribution of cells in different phases of the cell cycles in both subgroups of ID mice (Table 4). Both subgroups of ID mice had lower percentages of cells in $\mathrm{S}$ and $\mathrm{G}_{2}-\mathrm{M}$ phases than the PF and $\mathrm{C}$ groups (compare Tables 3 and 4). When data of iron-repleted mice were also analysed as a function of thymus atrophy, the mean indicators of iron status tended to be higher in mice without than those with thymus atrophy (Table 4$)$. In addition, repleted mice $\left(R_{1}\right.$ and $R_{3}$ groups) without thymus atrophy, also tended to have higher percentages of thymocytes in the $\mathrm{S}$ and $\mathrm{G}_{2}-\mathrm{M}$ phases, higher proliferative indexes, and lower percentages of thymocytes in the $G_{0}-G_{1}$ phase $\left(R_{1}\right.$ only). However, in no case were the differences between iron-repleted mice without and those with thymus atrophy statistically significant. Indicators of iron status positively and significantly correlated with the percentages of thymocytes in the $\mathrm{S}$ and $\mathrm{G}_{2}-\mathrm{M}$ phases, and they negatively correlated with the percentages of cells in the resting $\left(\mathrm{G}_{0}-\mathrm{G}_{1}\right)$ phase $(P<0 \cdot 05$; Table 5). 
Table 4. Distribution of thymocytes in different phases of the cell cycle iron-deficient (ID), and iron-repleted mice $\left(R_{1}\right)$ and $\left(R_{3}\right)$ with $(A)$ and without (B) thymus atrophy

(Values are means and their standard errors for $(n)$ mice per group)

\begin{tabular}{|c|c|c|c|c|c|c|c|c|c|c|c|c|}
\hline \multirow[b]{2}{*}{ Hemoglobin (g/l) } & \multicolumn{2}{|c|}{ ID-A (11) } & \multicolumn{2}{|c|}{ ID-B (16) } & \multicolumn{2}{|c|}{$\mathrm{R}_{1}-\mathrm{A}(3)$} & \multicolumn{2}{|c|}{$\mathrm{R}_{1}-\mathrm{B}(9)$} & \multicolumn{2}{|c|}{$\mathrm{R}_{3}-\mathrm{A}(10)$} & \multicolumn{2}{|c|}{$\mathrm{R}_{3}-\mathrm{B}(4)$} \\
\hline & $32 \cdot 1$ & $3 \cdot 42^{\mathrm{a}}$ & 41.89 & $2 \cdot 74$ & $39 \cdot 1$ & $2 \cdot 9$ & $48 \cdot 91$ & $6 \cdot 5$ & $58 \cdot 1$ & $6 \cdot 17$ & $66 \cdot 73$ & $5 \cdot 74$ \\
\hline Packed cell volume (\%) & $15 \cdot 5$ & $1 \cdot 28$ & $18 \cdot 75$ & $1 \cdot 23$ & $18 \cdot 7$ & $0 \cdot 67$ & 21.9 & $2 \cdot 1$ & $28 \cdot 1$ & $2 \cdot 17$ & $30 \cdot 75$ & $2 \cdot 9$ \\
\hline$\mu \mathrm{mol} \mathrm{Fe} / \mathrm{g}$ liver & 0.22 & 0.02 & 0.22 & 0.01 & 0.34 & 0.074 & 0.26 & 0.03 & 0.47 & 0.07 & 0.498 & 0.15 \\
\hline $\mathrm{G}_{0}-\mathrm{G}_{1}(\%)$ & 88.5 & 1.73 & 90.5 & 0.98 & $92 \cdot 6$ & $1 \cdot 87$ & $89 \cdot 3$ & 0.67 & $84 \cdot 7$ & 1.65 & 83.6 & 5.53 \\
\hline S (\%) & $9 \cdot 44$ & 1.48 & $7 \cdot 68$ & 0.86 & $6 \cdot 24$ & 1.52 & 8.81 & 0.56 & 12.5 & 1.41 & $13 \cdot 1$ & 4.19 \\
\hline $\mathrm{G}_{2}-\mathrm{M}(\%)$ & 2.06 & 0.31 & 1.83 & 0.16 & 1.19 & 0.35 & 1.97 & 0.18 & $2 \cdot 77$ & 0.34 & 3.32 & 1.44 \\
\hline$\left(\mathrm{S}+\left[\mathrm{G}_{2}-\mathrm{M}\right]\right)(\%)$ & 11.5 & 1.73 & $8 \cdot 7$ & 1.02 & 7.44 & 1.62 & 10.97 & 0.68 & 15 & 1.73 & $16 \cdot 4$ & 5.53 \\
\hline$\left(S+\left[G_{2} / M\right]\right) / G_{0}-G_{1}$ & 0.13 & 0.02 & $0 \cdot 1$ & 0.01 & 0.08 & 0.19 & 0.12 & 0.12 & 0.18 & 0.02 & 0.213 & 0.09 \\
\hline
\end{tabular}

$\mathrm{G}_{0}-\mathrm{G}_{1}$, resting phase of the normal cell cycle; $\mathrm{S}$, DNA synthesis phase; $\mathrm{G}_{2}-\mathrm{M}$, late phase of DNA synthesis and onset of mitosis.

For each dietary treatment group, no significant difference was observed between mice with and those without thymus atrophy; except for the mean haemoglobin levels of ID-A that were lower than the mean of ID-B ( $P<0.05$, ID-A compared to ID-B).

\section{Discussion}

It has been established that iron is required for the proliferation of lymphocytes and non-lymphoid cells. In normal lymphocytes and leukaemic cells, iron deprivation either by serum starvation or iron chelation by desferroxamine results in inhibition of cell proliferation (Fukuchi et al. 1995; Hileti et al. 1995). In addition, iron chelation has been shown to induce apoptosis in human leukaemic CCRF-CEM cells (Haq et al. 1995).

In this study, we tested the hypothesis that thymus atrophy associated with iron deficiency is a result of increased apoptosis and reduced thymocyte proliferation. In contrast to what we expected, there was no increase in the percentage of thymocytes undergoing apoptosis in ID mice compared to those from iron-sufficient mice. Instead, there was a significant decrease in the percentage of cells in the $S$ and $\mathrm{G}_{2}-\mathrm{M}$ phases. This is not very surprising considering that the function of ribonucleotide reductase, the enzyme required for the biosynthesis of deoxynucleotides, is highly iron dependent. Under the experimental conditions, it appears that intracellular iron concentrations in thymocytes are not decreased enough to induce apoptosis, but are low enough to reduce the rate of DNA synthesis.

In contrast to what one would expect, ID mice with atrophy did not differ from those without thymus atrophy for the distribution of thymocytes in different phases of the cell cycle. The reason for this discrepancy is not clear; however, we can speculate about the lack of differences in liver iron stores in both subgroups of mice and the small sample size. The second possible explanation is the fact that the mean (SE) thymus weights of the ID subgroup without thymus atrophy were still below normal (3.25 (SE $0 \cdot 2$ ) in ID and 4.0 (SE 0.26) for C mice). However, when ID mice were repleted for $1 \mathrm{~d}$, the expected trend was observed. $\mathrm{R}_{1}$ mice with thymus atrophy tended to have lower percentages of cells in the $S$ and $G_{2}-M$ phases than those without thymus atrophy.

The mechanism of thymus atrophy associated with iron deficiency differs from that observed during zinc deficiency and protein-energy malnutrition (Sunderman, 1995; DePascal-Jardieu \& Fraker, 1979). In both zinc deficient and protein-energy malnourished mice, there is an increase in apoptosis in the thymus which parallels an increase in plasma cortisol levels (Alleyne \& Young, 1967; DePascalJardieu \& Fraker, 1979). However, it is unknown whether there also is a decrease in the rate of DNA synthesis in thymocytes from such mice. It is also unknown whether ID mice have elevated plasma cortisol levels. Although our data suggest a decrease in the rate of DNA synthesis and mitosis in thymocytes from ID mice, the possibility of reduced proliferation of haematopoietic stem cell precursors of thymocytes from the bone marrow can not be ruled out. Considering the role of iron on ribonucleotide reductase activity in various tissues, it is highly likely that there is also reduced proliferation of precursor thymocytes in the bone marrow of ID mice. We do not believe that increased migration of thymocytes to peripheral lymphoid organs such as the spleen is responsible for thymus atrophy. Although, iron deficiency induces

Table 5. Correlation coefficients $(r)$ between indicators of iron status, thymus weight, and percentages of cells in different phases of the cell cycle

\begin{tabular}{|c|c|c|c|c|c|c|c|c|}
\hline & Haemoglobin & Packed cell volume & $\mu \mathrm{mol} \mathrm{Fe}$ & $\begin{array}{l}\text { Thymus } \\
\text { (mg) }\end{array}$ & $\begin{array}{c}\text { Thymus } \\
\text { (mg/g body weight) }\end{array}$ & $\begin{array}{c}\mathrm{G}_{0}-\mathrm{G}_{1} \\
(\%)\end{array}$ & $\begin{array}{l}\mathrm{S} \\
(\%)\end{array}$ & $\begin{array}{c}\mathrm{G}_{2}-\mathrm{M} \\
(\%)\end{array}$ \\
\hline Haemoglobin & 1 & & & & & & & \\
\hline Packed cell volume & $0.99^{*}$ & 1 & & & & & & \\
\hline$\mu \mathrm{mol} \mathrm{Fe}$ & $0.91^{*}$ & $0.9^{\star}$ & 1 & & & & & \\
\hline Thymus (mg) & $0.56^{*}$ & $0.55^{\star}$ & $0.46^{*}$ & 1 & & & & \\
\hline Thymus (mg/g body weight) & $0.44^{*}$ & $0.44^{*}$ & $0.39^{*}$ & $0.95^{*}$ & 1 & & & \\
\hline $\mathrm{G}_{0}-\mathrm{G}_{1}(\%)$ & $-0.24^{*}$ & $-0.24^{\star}$ & -0.17 & -0.13 & -0.09 & 1 & & \\
\hline $\mathrm{S}(\%)$ & $0 \cdot 19^{*}$ & $0 \cdot 19^{*}$ & 0.12 & 0.11 & 0.09 & $-0.99^{*}$ & 1 & \\
\hline $\mathrm{G}_{2}-\mathrm{M}^{\prime}(\%)$ & $0.37^{*}$ & $0.37^{*}$ & $0.3^{*}$ & 0.21 & 0.09 & $-0.83^{*}$ & $0.73^{*}$ & 1 \\
\hline
\end{tabular}

$\mathrm{G}_{0}-\mathrm{G}_{1}$, resting phase of the normal cell cycle; $\mathrm{S}$, DNA synthesis phase; $\mathrm{G}_{2}-\mathrm{M}$, late phase of DNA synthesis and onset of mitosis.

Almost all $r$ values are significantly different from zero $\left({ }^{\star} P<0.05\right)$ except for those not followed by an asterisk. 
splenomegaly in 50 to $60 \%$ of mice, the number of nucleated cells per gram of spleen, the percentage of antiThy $1 \cdot 2^{+} \mathrm{T}$ cells, helper (L3T4) $\mathrm{T}$ cells, and suppressor $\left(\right.$ anti-Lyt $2^{+}$) $\mathrm{T}$ cells are significantly reduced in ID mice (Kuvibidila et al. 1982, 1990). In summary, our data suggest that reduced thymocyte proliferation, but very unlikely increased apoptosis, is responsible of thymus atrophy associated with iron deficiency.

\section{Acknowledgements}

This work was supported by a grant from NIH (K14HL03144) and a special grant (Research Enhancement Funds) from the Dean of the Medical School, Louisiana State University Health Sciences Center. The authors thank Rene Gardner, MD and Ms Carole Lachney for their comments and suggestions during the planning of this study and preparation of this manuscript.

\section{References}

Abbas AK, Lichtman AH \& Pober JS (1997) T cell maturation in the thymus. In Cellular and Molecular Immunology, pp. 171193 [AK Abbas, AH Lichtman and JS Pober, editors]. Philadelphia, PA: WB Saunders.

Alleyne GA \& Young VH (1967) Adrenocortical function in children with severe protein-calorie malnutrition. Clinical Science 33, 189-200.

Becker DJ (1983) The endocrine responses to protein-calorie malnutrition. Annual Review of Nutrition 3, 187-212.

Chandra RK \& Newberne PM (1977) Nutrition, Immunity, and Infection. New York, NY: Plenum Press.

JJ Coligan, AM Kruisbeek, DH Margulies, EM Shevalies and W Strober, editors (1991) Current Protocols in Immunology, Section 5.7. New York, NY: Greene Publishing Associates and Wiley-Interscience.

DePascal-Jardieu P \& Fraker PJ (1979) The role of corticosterone in the loss in immune function in zinc-deficient $\mathrm{A} / \mathrm{J}$ mouse. Journal of Nutrition 109, 1847-1855.

Fukuchi K, Tomoyasu S, Watanabe H, Kaetsu S, Tsuruoka N \& Gomi K (1995) Iron deprivation results in an increase in p53 expression. Biological Chemistry (Hoppe Seyler) 376, 627630.

Hileti D, Panayiotidis P \& Hoffbrand AV (1995) Iron chelators induce apoptosis in proliferating cells. British Journal of Haematology 89, 181-187.

Haq RU, Wereley JP \& Chitambar CR (1995) Induction of apoptosis by iron deprivation in human leukemic CCRF-CEM cells. Experimental Hematology 23, 428-432.
Kochanowiski BA \& Sherman AR (1982) Serum and secretory proteins in iron-deficient rat pups and dams. Nutrition Research 2, 689-698.

Kuvibidila S, Baliga BS \& Suskind RM (1982) Generation of plaque-forming cells in iron deficient anemic. Nutrition Reports International 26, 861-872.

Kuvibidila S, Dardenne M, Savino W \& Lepol F (1990) Influence of iron deficiency anemia on selected thymus functions in mice: thymulin biological activity, T-cell subsets, and thymocyte proliferation. American Journal of Clinical Nutrition 51, 228232.

Kuvibidila S, Yu L, Ode D \& Warrier RP (1993) The immune response in protein-energy malnutrition and single nutrient deficiencies. In Human Nutrition: a Comprehensive Treatise Vol. 8, pp. 121-155 [DM Klufeld, editor]. New York, NY: Plenum Press.

Kuvibidila S, Baliga BS, Warrier RP \& Suskind RM (1998) Iron deficiency reduces the hydrolysis of cell membrane phosphatidyl inositol-4-5-bisphosphate during splenic lymphocyte activation in C57BL/6 mice. Journal of Nutrition 128, 10771083.

Kuvibidila SR, Kitchens D \& Baliga BS (1999) In vivo and in vitro iron-deficiency reduces protein kinase $\mathrm{C}$ activity and translocation in murine splenic and purified T cells. Journal of Cellular Biochemistry 74, 468-478.

Nauss KN, Mark D \& Suskind RM (1979) The effect of vitamin A deficiency on the in vitro cellular immune response of rats. Journal of Nutrition 109, 1815-1823.

Munro BH, Visintainer MA \& Page EB (1986) Differences among group means: one-way analysis: oneway analysis of variance. In Statistical Methods for Health Care Research, 1st edition, pp. 174-199 [BH Munro, MA Visintainer and EB Page, editors]. Philadelphia, PA: JB Lippincott Company.

Rodak BF (1992) Routine laboratory evaluation of erythrocytes. In Clinical Hematology: Principles, Procedures, Correlations, pp. 97-127 [CA Lotspeich-Steininger, EA Stiene-Martin and JA Koepke, editors]. Philadelphia, PA: JB Lippincott Company.

Smith HF, Latham MC, Azaburke JA, Butler WR, Phillips LS, Pond WG \& Enwonwu CO (1981) Blood plasma levels of cortisol, insulin, growth hormone, and somatomedin in children with marasmus, kwashiorkor, and intermediate forms of protein-energy malnutrition. Proceedings of the Society of Experimental Biology and Medicine 167, 607-611.

Smythe PM, Scholnland M, Brereton-Stiles G, Coovadra HM, Grace HJ, Loening WE, Mafoyane A, Parent MA \& Vos GA (1971) Thymolymphatic deficiency and expression of cell mediated immunity in protein-calorie malnutrition. Lancet $\mathbf{2}$, 939-944.

Sunderman FW Jr (1995) The influence of zinc on apoptosis. Annals of Clinical and Laboratory Science 25, 134-242. 